\title{
Analisis Hubungan Ca 15-3 dan Respon Kemoterapi Neoadjuvan pada Pasien Kanker Payudara Stadium Lanjut Lokal
}

\author{
Lie V. Rusli, ${ }^{1}$ Marselus Merung, ${ }^{2}$ Victor Pontoh ${ }^{\dagger}, 2$ Christian Manginstar, ${ }^{2}$ Mendy J. \\ Hatibie, ${ }^{3}$ Fredrik G. Langi ${ }^{4}$
}

\author{
${ }^{1}$ Program Pendidikan Dokter Spesialis Bagian Ilmu Bedah Fakultas Kedokteran Universitas \\ Sam Ratulangi, Manado, Indonesia \\ ${ }^{2}$ Divisi Bedah Onkologi Bagian Ilmu Bedah Fakultas Kedokteran Universitas Sam Ratulangi/ \\ RSUP Prof. Dr. R. D. Kandou, Manado, Indonesia \\ ${ }^{3}$ Divisi Bedah Plastik Bagian Ilmu Bedah Fakultas Kedokteran Universitas Sam \\ Ratulangi/RSUP Prof. Dr. R. D. Kandou, Manado, Indonesia \\ ${ }^{4}$ Fakultas Kesehatan Masyarakat, Epidemiologi dan Biostatistik, Universitas Sam Ratulangi \\ Manado \\ Email: lierusli013@ student.unsrat.ac.id
}

\begin{abstract}
Neoadjuvant chemotherapy is one of the therapeutic modalities used in the management of locally advanced breast cancer. Therapeutic response can be objectively assessed with RECIST and Ca 15-3 could be used to monitor response to breast cancer (BC) treatment. This study was aimed to prove the relationship between $\mathrm{Ca}$ 15-3 and response to neoadjuvant chemotherapy in locally advanced BC. The study was carried out at the Departement of Surgery Prof. Dr. R. D. Kandou Hospital Manado using a single-arm pre-post trial. Each patient would be performed Ca 15-3 test and clinical assessment (RECIST) pre and post chemotherapy for two sessions. There were $11 \mathrm{BC}$ patients with invasive ductal carcinoma. The average age was 60 years old and the majority had anemia and lymphocytopenia. There was a decrease in Ca 15-3 in each patient by a baseline of $21.8 \mathrm{U} / \mathrm{mL}$ pre-treatment and a decrease in the lesion size by 30.3 $\mathrm{mm}$ using RECIST. The results showed that changes in RECIST and Ca 15-3 level were correlated with each unit change in RECIST was associated with a decrease in Ca 15-3 level by 0.03 units $(\mathrm{p}=0.019)$. In conclusion, there was a decrease in Ca 15-3 level in response to chemotherapy, followed by a decrease in RECIST. There was a relationship between Ca 15-3 level and chemotherapy response assessed with RECIST after the second chemotherapy.
\end{abstract}

Keywords: Ca 15-3, chemotherapy response, neoadjuvant chemotherapy, RECIST, breast cancer

\begin{abstract}
Abstrak: Kemoterapi neoadjuvan masih merupakan pilihan utama terapi untuk kanker payudara (KPD) stadium lanjut local. Respon suatu kemoterapi dapat dinilai secara objektif dengan RECIST dan Ca 15-3 dapat digunakan untuk memantau respon terhadap pengobatan KPD. Penelitian ini bertujuan untuk membuktikan hubungan antara Ca 15-3 dengan respon kemoterapi neoadjuvan RECIST pada pasien KPD stadium lanjut lokal. Penelitian dilaksanakan di Bagian Bedah RSUP Prof. Dr. R. D. Kandou, Manado dengan menggunakan single-arm pre-post trial. Setiap individu yang terlibat akan diperiksa kadar Ca 15-3, serta penilaian RECIST sebelum dan sesudah mereka menerima kemoterapi selama dua sesi. Hasil penelitian mendapatkan 11 pasien KPD dengan karsinoma duktal invasif. Rerata usia 60 tahun, umumnya dengan anemia dan limfositopenia. Terdapat penurunan $\mathrm{Ca}$ 15-3 pada tiap pasien sebesar awal 21,8 U/mL pra pengobatan dan penurunan lesi $30,3 \mathrm{~mm}$ saat dinilai menurut RECIST. Didapatkan bahwa perubahan RECIST dan Ca 15-3 memiliki keterkaitan dengan setiap unit perubahan RECIST berhubungan dengan penurunan kadar Ca 15-3 sebesar 0,03 unit ( $\mathrm{p}=0,019)$. Simpulan penelitian ini ialah terdapat hubungan antara kadar Ca 15-3 dengan respon kemoterapi setelah kemoterapi siklus ke dua.
\end{abstract}

Kata kunci: Ca 15-3; respon kemoterapi; neoadjuvan kemoterapi; RECIST; kanker payudara 


\section{PENDAHULUAN}

Berdasarkan data dari World Health Organization (WHO) yang disadur dari Global Cancer Observatory (GLOBOCAN 2020) kanker payudara (KPD) menduduki peringkat pertama dari insidens kanker di dunia yaitu sebesar $65.858(16,6 \%)$ dan menyebabkan angka mortalitas kedua sesudah kanker paru yaitu sebesar 22.430 $(9,6 \%){ }^{1}$ Sebagian besar kasus baru yaitu $70 \%$ KPD dalam stadium lanjut (III dan IV).

Saat ini penanda tumor lain yang direkomendasikan dan sering digunakan untuk melihat respon terapi, prognosis, serta metastasis dari KPD ialah serum Ca 15-3. ${ }^{2}$ Ca 15-3 menghasilkan inti sel yang identik dan diekspresi berlebihan pada KPD sehingga $\mathrm{Ca}$ 15-3 dapat digunakan sebagai penanda tumor. ${ }^{3}$

Sampai saat ini kemoterapi neoadjuvan masih merupakan pilihan utama terapi untuk KPD stadium lanjut lokal. Respon kemoterapi dapat dinilai secara objektif dengan pengukuran massa tumor sesudah kemoterapi yaitu dengan menggunakan pengukuran RECIST (response evaluation criteria in solid tumor). ${ }^{4}$ Mengingat tingginya insidensi KPD maka penulis tertarik untuk membuktikan hubungan antara $\mathrm{Ca}$ 15-3 dengan respon kemoterapi neoadjuvan pada pasien KPD stadium lanjut lokal.

\section{METODE PENELITIAN}

Penelitian ini dilaksanakan di Bagian Bedah RSUP Prof. Dr. R. D. Kandou Manado sejak bulan Juli hingga Oktober 2020 dengan menggunakan rancangan single-arm pre-post trial.

Pasien bersedia untuk berpartisipasi dalam penelitian dengan menandatangani surat persetujuan (informed consent). Kriteria inklusi ialah pasien dengan KPD stadium lanjut lokal (IIIA, IIIB, IIIC), dengan hasil patologi anatomi karsinoma invasif duktal, mengunakan kemoterapi regimen cisplatin $80 \mathrm{mg} / \mathrm{BSA}$ dan gemcitabine dosis $1000 \mathrm{mg} / \mathrm{BSA}$ diberikan sebanyak 2 siklus, dan indeks Karnofsky $>70$, sedangkan kriteria eksklusi ialah pasien yang menjalani radioterapi bersamaan dengan kemoterapi, adanya keganasan atau kelainan hematologi sebelumnya, KPD bilateral, pasien yang pindah regimen kemoterapi, maupun pasien yang mengalami gangguan metabolisme/penyakit penyerta yang menyebabkan tertundanya kemoterapi.

Pengukuran kadar Ca 15-3 dan RECIST dilakukan sebelum dan sesudah kemoterapi selama dua siklus atau sekitar lima minggu pengobatan. Analisis statistik dilakukan melalui software statistik $\mathrm{R}$ versi 3.6.2 (The $R$ Foundation). Untuk variabel numerik dengan distribusi normal, nilai diberikan dalam bentuk mean dan standar deviasi (SD). Bila ketidak normalan distribusi dapat dibuktikan, nilai median dan rentang antar kuartil (interquartile range, IQR) yang justru diberikan. Untuk variabel kategori, nilai proporsi ditampilkan pada masingmasingnya. Perbedaan karakteristik pasien menurut waktu pengambilan sampel (sebelum dan sesudah kemoterapi) selanjutnya diberikan dan diuji menggunakan uji $t$ ataupun Mann-Whitney U untuk variabel numerik, dan uji chi-square atau Fisher's Exact untuk variabel kategori. Evaluasi pengaruh kemoterapi terhadap kadar Ca 153 dilakukan dengan menilai perubahan nilai masing-masing outcome sebelum dan sesudah pelaksanaan kemoterapi menggunakan uji dua sampel berpasangan.

Penelitian ini telah mendapat persetujuan dari Komisi Etik Penelitian Kesehatan RSUP Prof. Dr. R. D. Kandou Manado, dengan nomor keterangan layak etik yaitu No. 048/EC/KEPK-KANDOU/ VI/2020.

\section{HASIL PENELITIAN}

Sebanyak sebelas pasien KPD stadium lanjut lokal berpartisipasi dalam penelitian ini. Tabel 1 memperlihatkan karakteristik pasien yang menjalani kemoterapi selama dua siklus. Usia rerata ialah 60 tahun namun dengan variasi besar sekitar 10 tahun. Median IMT mengindikasikan kecenderungan para pasien dalam kisaran nilai normal. Kadar leukosit dan trombosit juga relatif normal pada umumnya, namun mean hemoglobin menunjukkan kondisi anemia pada kebanyakan pasien $(11,6 \pm 2,4 \mathrm{~g} / \mathrm{dL})$. Tingkat monosit umumnya baik, tetapi nilai median limfosit dan kuartilnya (25\%; IQR 
21\%-31\%) agak mengesankan limfositopenia.

Tabel 2 memperlihatkan perubahan kadar Ca 15-3 dan RECIST secara keseluruhan. Hasil studi mengindikasikan adanya penurunan baik dalam kadar $\mathrm{Ca} 15-3$, dan
RECIST pasca kemoterapi. Kadar Ca 15-3 juga turun sekitar 2,1 U/mL dari kuantitas awal 21,8 U/mL pra pengobatan (Gambar 1). Sementara itu, diameter target lesi para pasien rata-rata turun $30,3 \mathrm{~mm}$ saat dinilai menurut RECIST (Gambar 2).

Tabel 1. Karakteristik pasien pada awal penelitian

\begin{tabular}{lcc}
\hline Karakteristik & Mean \pm SD & Median $(\mathbf{Q 1} ; \mathbf{Q 3})$ \\
\hline Usia & $60,4 \pm 10,1$ & $*$ \\
IMT $\left(\mathrm{kg} / \mathrm{m}^{2}\right)$ & $*$ & $22,0(21,0 ; 27,0)$ \\
Leukosit $\left(\times 10^{3} \mathrm{umL}\right)$ & $8,4 \pm 3,6$ & $*$ \\
Hemoglobin $(\mathrm{g} / \mathrm{dL})$ & $11,6 \pm 2,4$ & $*$ \\
Trombosit $(\times 103=\mathrm{mL})$ & $220,0 \pm 122,5$ & $*$ \\
Eosinofil $(\%)$ & $57,3 \pm 20,6$ & $1,0(0,0 ; 3,0)$ \\
Netrofil $(\%)$ & & $*$ \\
Limfosit $(\%)$ & $6,2 \pm 3,6$ & $* 25,0(21,0 ; 31,0)$ \\
Monosit $(\%)$ & $193,1 \pm 34,8$ & $*$ \\
Kolesterol $(\mathrm{mg} / \mathrm{dL})$ & $43,5 \pm 14,0$ & $*$ \\
HDL $(\mathrm{mg} / \mathrm{dL})$ & $118,8 \pm 39,8$ & $*$ \\
LDL $(\mathrm{mg} / \mathrm{dL})$ & $187,8 \pm 77,1$ & $*$ \\
Trigliserida $(\mathrm{mg} / \mathrm{dL})$ & & \\
\hline
\end{tabular}

Catatan: SD, standar deviasi; Q1, kuartil I; Q3, kuartil III; IMT, indeks massa tubuh' LDL, low-density lipoprotein; HDL, high-density lipoprotein

Tabel 2. Nilai RECIST, Ca 15-3, dan para pasien pra dan pasca kemoterapi, serta besar perubahannya

\begin{tabular}{lccccccc}
\hline Variabel & \multicolumn{2}{c}{ Pra-kemoterapi } & \multicolumn{2}{c}{ Pasca kemoterapi } & \multicolumn{2}{c}{ Delta } & \\
& Mean & Median & Mean & Median & Mean & Median & $\mathrm{p}^{\mathrm{a}}$ \\
& $(\mathrm{SD})$ & $(\mathrm{Q} 1-\mathrm{Q} 3)$ & $(\mathrm{SD})$ & $(\mathrm{Q} 1-\mathrm{Q} 3)$ & $(\mathrm{SD})$ & $(\mathrm{Q} 1-\mathrm{Q} 3)$ & \\
\hline RECIST & 51,2 & $*$ & 20,9 & $*$ & $-30,3$ & $*$ & 0,002 \\
$(\mathrm{~mm})$ & $(40,2)$ & & $(30,0)$ & & $(23,6)$ & & \\
CA 15-3 & $*$ & 21,8 & $*$ & 15,0 & $*$ & $-2,1$ & 0,001 \\
$(\mathrm{U} / \mathrm{mL})$ & & $(16,3-34,7)$ & & $(13,3-29,6)$ & & $(-5,9--1,9)$ & \\
\hline
\end{tabular}

Catatan: SD, standar deviasi; Q1, kuartil I; Q3, kuartil III; RECIST, Response Evaluation Criteria in Solid Tumours, factor; $\mathrm{CA}$, cancer antigen. Hasil uji t berpasangan ataupun uji ranking bertanda Wilcoxon untuk delta perubahan

Boxplot of Ca.15.3_pre

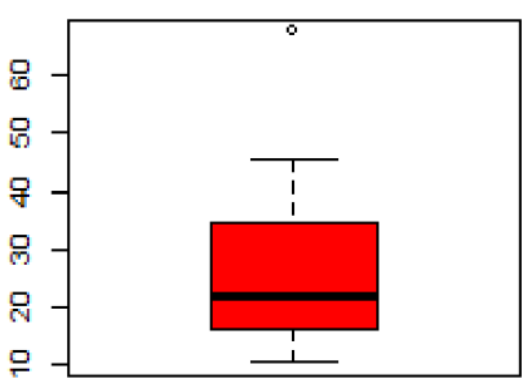

Boxplot of Ca.15.3_post

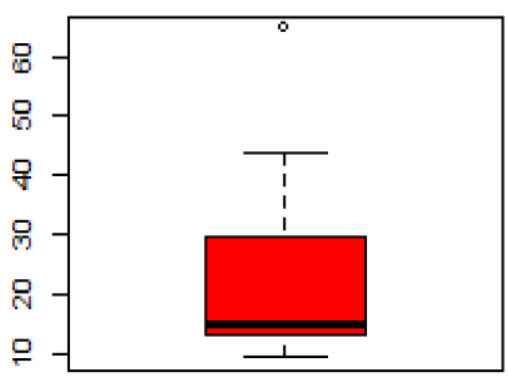

Gambar 1. Perubahan kadar Ca 15-3 pada waktu sebelum dilakukan kemoterapi dan setelah kemoterapi siklus ke II 
Boxplot of RECIST_pre

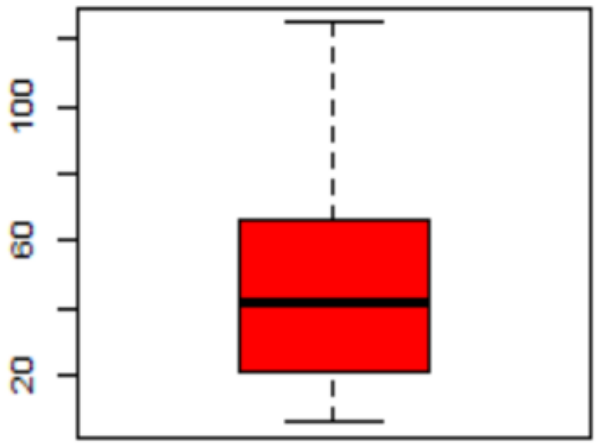

Boxplot of RECIST_post

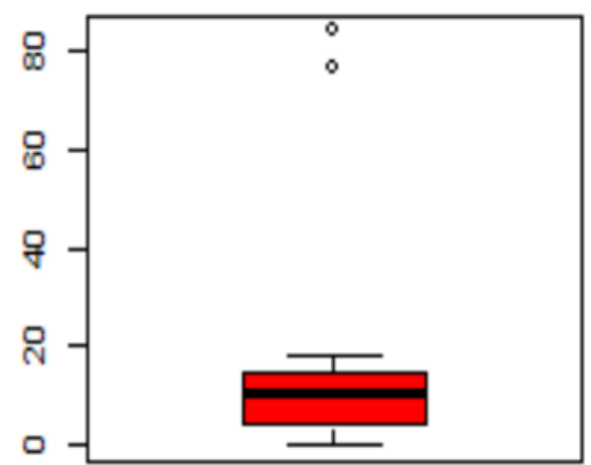

Gambar 2. Perubahan ukuran tumor menurut RECIST pada waktu sebelum dilakukan kemoterapi dan setelah kemoterapi siklus ke II

Tabel 3. Model regresi linear perubahan RECIST, Ca 15-3

\begin{tabular}{lcccc}
\hline & \multicolumn{4}{c}{ Outcome Model Regresi $^{\mathbf{a}}$} \\
RECIST & & \multicolumn{2}{c}{ Ca 15-3 } & \\
& $B(95 \% \mathrm{CI})$ & $\mathrm{p}$ & $\beta(95 \% \mathrm{CI})$ & $\mathrm{p}$ \\
\hline RECIST & $*$ & & $-0,03(-0,05 ;-0,01)$ & 0,019 \\
$\mathrm{Ca} 15-3$ & $-3,67(-9,07 ; 1,73)$ & 0,158 & $*$ & \\
\hline
\end{tabular}

Catatan: CI confidence interval, RECIST Response Evaluation Criteria in Solid Tumours, CA cancer antigen Semua outcome adalah nilai selisih pasca minus pra-kemoterapi. Seluruh model dijalankan sebagai regresi univariabe

Tabel 3 memperlihatkan hubungan perubahan Ca 15-3 dan RECIST dan hanya perubahan RECIST dan $\mathrm{Ca}$ 15-3 yang memiliki keterkaitan. Setiap unit perubahan RECIST berhubungan dengan penurunan kadar Ca 15-3 sebesar 0,03 unit (95\% CI 0,$05 ;-0,01$ dan $\mathrm{p}=0,019$ ) tetapi hubungan ini tidak timbal balik. Setiap unit perubahan kadar $\mathrm{Ca}$ 15-3 sesuai data menurunkan perubahan RECIST dengan rerata 3,67 $\mathrm{mm}$.

\section{BAHASAN}

Penelitian ini mencakup 11 pasien yang memenuhi kriteria inklusi dan eksklusi di RSUP Prof. Dr. R. D. Kandou, Manado. Tabel 1 memperlihatkan salah satu hal terpenting dalam faktor risiko KPD ialah sangat erat kaitannya dengan pertambahan usia. Pada tahun 2016, sekitar 99,3\% dan 71,2\% dari seluruh kematian terkait kanker di Amerika dilaporkan pada wanita di atas usia 40 tahun dan 60 tahun. ${ }^{5}$ Gnerlich et $\mathrm{al}^{6}$ pada tahun 2009 meneliti kejadian KPD berdasarkan usia dan stadium, dan melaporkan bahwa pasien KPD terbanyak pada usia $>40$ tahun. American Cancer Society juga menyatakan bahwa pasien KPD lebih banyak pada usia $>40$ tahun dibandingkan $<40$ tahun. $^{7}$ Hal ini sesuai dengan hasil penelitian ini yaitu pasien dengan gambaran histologik karsinoma duktal invasif secara umum dengan rerata usia 60 tahun. Adanya kesamaan tersebut kemungkinan disebabkan karena umumnya pasien KPD yang datang berobat ialah yang sudah berusia 5060 tahun.

Kesan anemia dapat terlihat pada keseluruhan subjek penelitian ini dengan mean hemoglobin 11,6 $22,4 \mathrm{~g} / \mathrm{dL}$. Anemia pada pasien KPD disebut cancer-related anemia (CRA) yang disebabkan terjadinya kegagalan proses eritropoeisis yang disebabkan oleh sel-sel kanker. Menurut European Cancer Anemia Survey, sekitar 33\% penderita kanker sebelum dilakukan kemoterapi mengalami anemia dan $67 \%$ setelah kemo- 
terapi yang disebut chemotherapy-induced anemia (CIA). ${ }^{8} \mathrm{Xu}$ et $\mathrm{al}^{9}$ menyatakan bahwa lebih dari $75 \%$ pasien kanker yang sedang menjalani kemoterapi dan atau radioterapi mengalami anemia ringan-sedang dengan kadar hemoglobin 9-11 g/dL.

Pada pasien dengan kemoterapi baik dengan kemoterapi neoadjuvan dan kemoterapi adjuvan, dapat terjadi efek samping berupa depresi sumsum tulang yang berdampak pada penurunan jumlah leukosit termasuk limfosit. Hal ini sesuai dengan patomekanisme sistem imun pada KPD dimana limfosit cukup banyak berperan. Nilai limfosit pada penelitian ini mengesankan limfositopenia dengan median limfosit dan kuartilnya sebesar 25\%; IQR 21\%-31\%.

Secara keseluruhan, hasil studi ini mengindikasikan adanya penurunan baik dalam kadar $\mathrm{Ca}$ 15-3, maupun RECIST. Telah diketahui bahwa Ca 15-3 (juga dikenal sebagai musin 1) diekspresikan secara berlebihan pada pasien KPD yaitu $>90 \%$. Ca 15-3 mendorong invasi tumor dan metastasis melalui aktivasi jalur pensinyalan protein kinase yang diaktivasi oleh mitogen dan meregulasi turunnya E-cadherin. Kadar Ca 15-3 juga umumnya meningkat pada KPD stadium lanjut. Park et $\mathrm{al}^{10}$ dalam penelitiannya juga mendapatkan peningkatan kadar Ca 15-3 pada KPD, terutama stadium III dan IV. American Society of Clinical Oncology 2007 (ASCO) menyebutkan bahwa kadar Ca 15-3 meningkat sekitar 75-90\% pada stadium lanjut dan metastasis. Demikian pula European Group on Tumor Markers Recommendations (EGTM) menyebutkan bahwa kadar abnormal Ca 15-3 ditemukan pada $50-70 \%$ penderita KPD stadium lanjut dan metastasis. Ca 15-3 mempunyai sensitivitas dan spesifitas yang rendah pada tahap awal penyakit dan akan meningkat sejalan dengan semakin lanjutnya perjalanan penyakit. Peningkatan kadar Ca 15-3 akan memrediksi prognosis buruk dengan peningkatan risiko metastasis. ${ }^{11}$

Pada penelitian ini terjadi penurunan kadar Ca 15-3 sekitar 2,1 U/mL dari kuantitas awal 21,8 U/mL pra kemoterapi kedua $(\mathrm{p}=0,001)$. Hasil penelitian ini sejalan dengan penelitian oleh Kurebayashi et $\mathrm{al}^{12}$ yang melaporkan adanya perubahan kadar Ca 15-3 setelah kemoterapi neoadjuvan yang merupakan faktor prediksi terhadap terapi yang diberikan. Hal ini juga didukung oleh Kresno et a ${ }^{13}$ yang menyatakan bahwa Ca 15-3 berkorelasi dengan keberhasilan pengobatan dan respon terapi.

Penilaian respon kemoterapi digunakan untuk memrediksi angka ketahanan hidup pasien dan dapat menjadi pedoman untuk kemoterapi selanjutnya. Penyusutan ukuran tumor (respons obyektif) menurut RECIST merupakan target penting dalam evaluasi respon kemoterapi. ${ }^{11,14,15}$ Data penelitian ini menunjukkan bahwa secara bermakna terjadi penurunan massa tumor yang diukur untuk menentukan respon kemoterapi. Penurunan target lesi pada pasien dengan rerata $30,3 \mathrm{~mm}$ saat dinilai menurut RECIST. Respon parsial terjadi pada 10 pasien dan respon komplit pada satu pasien. Menurut Rajan et al, ${ }^{16}$ respon klinis parsial dan respon patologi parsial merupakan hal yang dominan (60-80\%), sedangkan respon komplit mempunyai frekuensi yang lebih rendah $(3-30 \%)$.

Tabel 3 memperlihatkan hubungan perubahan kadar Ca 15-3 dengan RECIST. Penurunan RECIST dan Ca 15-3 yaitu setiap unit perubahan RECIST berhubungan dengan penurunan kadar $\mathrm{Ca}$ 15-3 sebesar 0,03 unit dengan $95 \%$ CI $-0,05 ;-0,01$ dan $\mathrm{p}=0,019$ sehingga dapat memberikan prognosis terhadap pasien dan juga menunjukkan respon terhadap pengobatan. Hal ini sesuai dengan hasil penelitian Kurebayashi et al $^{12}$ yang menunjukkan bahwa pengurangan lebih dari $20 \%$ kadar Ca 15-3 pada pengobatan sistemik berkorelasi dengan respons terhadap pengobatan yang memberikan faktor prediktif yang menguntungkan saat memantau perkembangan penyakit selama terapi.

\section{SIMPULAN}

Terdapat penurunan kadar Ca 15-3 dan RECIST setelah dilakukan pemberian neoadjuvan kemoterapi siklus ke dua pada pasien kanker payudara, dan terdapat hubungan antara $\mathrm{Ca}$ 15-3 dan respon kemoterapi neoadjuvan pada kanker payudara stadium lanjut lokal 


\section{Konflik Kepentingan}

Penulis menyatakan tidak terdapat konflik kepentingan dalam studi ini.

\section{DAFTAR PUSTAKA}

1. Country-specific I, Method N, Country-specific M. 273523 621. 2021;858:2020-1.

2. Yonemori K, Katsumata N, Noda A, Uno H, Yunokawa M, Nakano E, et al. Development and verification of a prediction model using serum tumor markers to predict the response to chemotherapy of patients with metastatic or recurrent breast cancer. J Cancer Res Clin Oncol. 2008;134(11):1199-206.

3. Al-Azawi D, Kelly G, Myers E, McDermott EW, Hill ADK, Duffy MJ, et al. CA 153 is predictive of response and disease recurrence following treatment in locally advanced breast cancer. BMC Cancer. 2006;6:3-9.

4. Eisenhauer EA, Therasse P, Bogaerts J, Schwartz LH, Sargent D, Ford R, et al. New response evaluation criteria in solid tumours: Revised RECIST guideline (version 1.1). Eur J Cancer [Internet]. 2009;45(2):228-47. Available from: http://dx.doi.org/10.1016/j.ejca.2008.10 .026

5. Sun YS, Zhao Z, Yang ZN, Xu F, Lu HJ, Zhu $\mathrm{ZY}$, et al. Risk factors and preventions of breast cancer. Int $\mathbf{J}$ Biol Sci. 2017;13(11):1387-97.

6. Gnerlich JL, Deshpande AD, Jeffe DB, Sweet A, White N, Margenthaler JA. Elevated breast cancer mortality in women younger than age 40 years compared with older women is attributed to poorer survival in early-stage disease. J Am Coll Surg. 2009;208(3):341-7.

7. Shumway DA, Sabolch A, Jagsi R. Controversies in Radiation Oncology. In: Lo S, Teh B, Jiang GL, Mayr N, editors. Breast Cancer. Medical Radiology. Springer, Cham, 2016; p. 1-43. Available from: https://doi.org/10.1007 /174_2016_83
8. Ludwig $\mathrm{H}$, Van Belle S, Barrett-Lee $\mathrm{P}$, Birgegård $\mathrm{G}$, Bokemeyer $\mathrm{C}$, Gascón $\mathrm{P}$, et al. The European Cancer Anaemia Survey (ECAS): a large, multinational, prospective survey defining the prevalence, incidence, and treatment of anaemia in cancer patients. Eur $\mathbf{J}$ Cancer. 2004;40(15):2293-306.

9. Xu H, Xu L, Page JH, Cannavale K, Sattayapiwat $\mathrm{O}$, Rodriguez $\mathrm{R}$, et al. Incidence of anemia in patients diag-nosed with solid tumors receiving chemotherapy, 20102013. Clin Epidemiol. 2016;8:61-71.

10. Park BW, Oh JW, Kim JH, Park SH, Kim KS, Kim JH, et al. Preoperative CA 15-3 and CEA serum levels as predictor for breast cancer outcomes. Ann Oncol. 2008; 19(4):675-81.

11. Duffy MJ. CA 15-3 and related mucins as circulating markers in breast cancer. Ann Clin Biochem. 1999;36(5):579-86.

12. Kurebayashi J, Nishimura R, Tanaka K, Kohno N, Kurosumi M, Moriya T, et al. Significance of serum tumor markers in monitoring advanced breast cancer patients treated with systemic therapy: a prospective study. Breast Cancer. 2004;11(4):389-95.

13. Kresno SB. Ilmu Dasar Onkologi [Internet] (2nd ed). Jakarta: Badan Penerbit FKUI, 2011. Available from: http://lib.ui.ac.id/ detail.jsp?id=135988

14. Smerage JB, Hayes DF. The measurement and therapeutic implications of circulating tumour cells in breast cancer. $\mathrm{Br} \mathbf{~ J}$ Cancer. 2006;94(1):8-12.

15. Sparano JA, Goldstein LJ, Childs BH, Shak S, Brassard D, Badve S, et al. Relationship between topoisomerase 2A RNA expression and recurrence after adjuvant chemotherapy for breast cancer. Clin Cancer Res. 2009;15(24):7693-700.

16. Rajan R, Poniecka A, Smith TL, Yang Y, Frye $\mathrm{D}$, Pusztai L, et al. Change in tumor cellularity of breast carcinoma after neoadjuvant chemotherapy as a variable in the pathologic assessment of response. Cancer. 2004;100(7):1365-73. 